\title{
Investigation of sustainable national water resources management of India in a changing climate
}

\author{
$\underline{\text { Naveen Joseph }^{1}}$, Dongryeol Ryu ${ }^{1}$, Hector Malano ${ }^{1}$, Biju George $^{2}$ and K P Sudheer ${ }^{3}$ \\ ${ }^{I}$ Department of Infrastructure Engineering, University of Melbourne, Melbourne, Australia \\ ${ }^{2}$ Integrated Water and Land Management Program, ICARDA, Cairo, Egypt \\ ${ }^{3}$ Dept. of Civil Engineering, IIT Madras, Chennai, Tamilnadu, India \\ Email:naveenj@student.unimelb.edu.au
}

\begin{abstract}
Freshwater scarcity and unsustainable water use is a growing concern in many developing countries including India. Increasing water demand coupled with rainfall variability associated with climate change exacerbates water scarcity. The increase in water demand is attributed to population and economic growth as well as technological change, and the gap between the actual water available and the demand continues to widen. This study aims to develop a large-scale assessment model of sustainable water use in India during the period 1970 - 2010 at a spatial resolution of $50 \mathrm{~km}$ x $50 \mathrm{~km}$ and a temporal resolution of monthly timescale.
\end{abstract}

A Community Land Model CLM 4.0, developed by the National Centre for Atmospheric Research (NCAR) of the US, and census-based statistical database are used in this study to quantify and assess the sustainable water use in India. We define the measure of sustainable water use as the difference between the total water available and the total water demand. For each grid cell, the total water available is modelled as the sum of surface runoff and groundwater. The total water demand is estimated as the sum of irrigation, industrial, domestic and environmental water demand in each grid cell. Among the demands, the irrigation water demand is modelled based on census data sets of irrigated areas and irrigation water withdrawal while the domestic and industrial water demand is modelled as a function of population, economic and technological indicators such as gross domestic product, electricity, fuel consumption and industrial outputs. However, the environmental water demand is modelled as a function of total water available, following hydrology based approach, with seasonal variation of water demand to meet the various ecosystem services considered.

Based on preliminary analysis, the rate of increase in industrial water demand ( $\sim 2 \%$ increase per annum) and domestic water demand $(\sim 1.2 \%$ increase per annum) is higher than the rate of increase in irrigation water demand, thus increasing contribution to the water scarcity in the country ( $\sim 54 \%$ of total population)._This rapid growth in industrial and domestic water demand highlights the importance of accurate projection of the future demand. Modelled results of industrial and domestic water demand closely match the observations obtained from the National Commission on Integrated Water Resources Development (NCIWRD) of India. The modelled results are shown to be superior to FAO (Food and Agriculture Organization) estimates of industrial water demand. The difference may be associated with the fact that the FAO estimates do not consider the water requirement for power production in the quantification of industrial water demand.

Keywords: $\quad$ Sustainable water use, water scarcity, water demand, environmental water requirement 
Joseph et al., Investigation of sustainable national water resources management of India in a changing climate

\section{INTRODUCTION}

India is one of the countries experiencing severe freshwater scarcity owing to the increasing water demand and changing climate. Around one billion people in India experience water scarcity for at least one month a year (Mekonnen and Hoekstra, 2016). The increasing water demand has widened the gap between the actual available water and the demand within the country, leading to the destruction of aquatic ecosystem (Rosegrant et al., 2009). Among the demands, the irrigation water demand alone constitutes around 70\% $80 \%$ of the total and the rapid increase in the past 50 years is attributed primarily to the 'Green Revolution' in India (Kumar, 2003). Moreover, rapidly growing population and economic and technological development have resulted in increased growth of domestic and industrial water demand in the country (Seckler et al., 2000; Amarasinghe et al., 2005). The demands are projected to increase significantly, with demand for industrial requirements doubling from 56 Billion Cubic Metre (BCM) to $100 \mathrm{BCM}$, domestic and irrigation requirements increasing from 43 to $66 \mathrm{BCM}$ and 557 to $611 \mathrm{BCM}$ from 2010 to 2025 respectively, thus necessitating a sharper focus on sustainability of water abstraction in India (Bhat, 2014).

A large-scale water resource assessment of the country helps to quantify and assess the sustainability and future water scarcity challenges in the country. Although many global-scale water scarcity assessment studies have quantified freshwater scarcity at a small spatial scale such as sub-catchment level, the assessment has been carried out at the annual time scale; hence the seasonal fluctuations were not taken into consideration (Oki et al., 2001; Alcamo et al., 2007; Hanasaki et al., 2008; Kummu et al., 2010). Moreover, the majority of these assessments focus on quantifying irrigation water demand while other demands such as domestic and industrial are estimated using population, economic and technological development indicators such as gross domestic product and electricity consumption (Hanasaki et al., 2008; Kummu et al., 2010). Furthermore, environmental water demand is neglected by the majority of these studies, which result in an incorrect estimate of freshwater scarcity (Oki et al., 2001; Alcamo et al., 2007; Kummu et al., 2010; Wada et al., 2011 b; Wada et al., 2014). Thus, there is an increasing need to quantify and assess the sustainable water use in India using a comprehensive framework that encompasses the quantification of available water and various water demands using the census-based statistical database. Based on these motivations, the present study focus on the large-scale assessment of sustainable water use in India using the census-based statistical database, at a spatial resolution of state and monthly time-scale.

The scope of the study is limited to assess the sustainable water use in India by quantifying total available water and the various water demands. The large-scale terrestrial water cycle is the basis of modelling total available in this study. Rather than relying on small-scale sources of supply from water authorities, reservoirs and transfer of water between river basins, the study focus on the primary source of supply, precipitation and resulting runoff. The Community Land Surface Model (CLM 4.0) is used in this study to quantify the surface water component (Oleson et al., 2010). The various water demands considered include the irrigation, industrial, domestic and environmental water demand. This study proposes new methods to estimate these water demands based on census data collected from National and State governmental organisations. Irrigation water demand is estimated based on irrigated area data-set, industrial water demand based on industrial production data-set and domestic water demand based on population and Gross Domestic Product (GDP) data-set collected at state-level from National Commission on Integrated Water Resources Development (NCIWRD, 1999).

\subsection{Objective of the study}

This study aims to quantify and assess water availability and water demands in India during the period 1970 to 2010 using a land surface model CLM 4.0 and census-based statistical database. This paper presents the preliminary results of the components surface water, industrial water demand and domestic water demand. The study follows the framework in Figure 1 and the methods of estimation of the components are discussed in the following sections.

\section{METHODS}

Figure 1 illustrates the modelling framework adopted in this study. The sustainability measure in this study is defined as the difference between the total available water and the total water demand. The total available water includes surface water and groundwater. Irrigation water demand is estimated using census data sets of irrigated areas and water withdrawal data-set. Previous studies used country-wide irrigated areas (Alcamo et al., 2000), global crop calendar (Siebert and Döll, 2010) and Food and Agricultural Organization (FAO) estimates of water withdrawal for irrigation (Hoekstra et al., 2012). The present study differs from these 
Joseph et al., Investigation of sustainable national water resources management of India in a changing climate

studies as census data-set collected from State and National government agencies are used to estimate irrigation water demand.

There is a paucity of information about industrial water use and observations of actual water withdrawals for industries in India. Hence in this study, industrial production data along with the economic and technological development indicators are used to model industrial water use at the State-level. Although many large-scale assessments estimate domestic water demand, most of them modelled domestic water demand as a function of population alone (Alcamo et al., 2003; Wada et al., 2011a; Wada et al., 2011b; Hoekstra and Mekonnen, 2012). However, economic and technological development combined with changes in living standards have influenced per-capita water use (Oki and Kanae, 2006). To account for these impacts, the change in percapita domestic water demand is modelled in this study using changes in the gross domestic product. Lastly, environmental water demand is estimated following a hydrology-based approach that follows a seasonally different threshold percentage of river flow allocated to the environment (Smakhtin et al., 2004; Pastor et al., 2014).

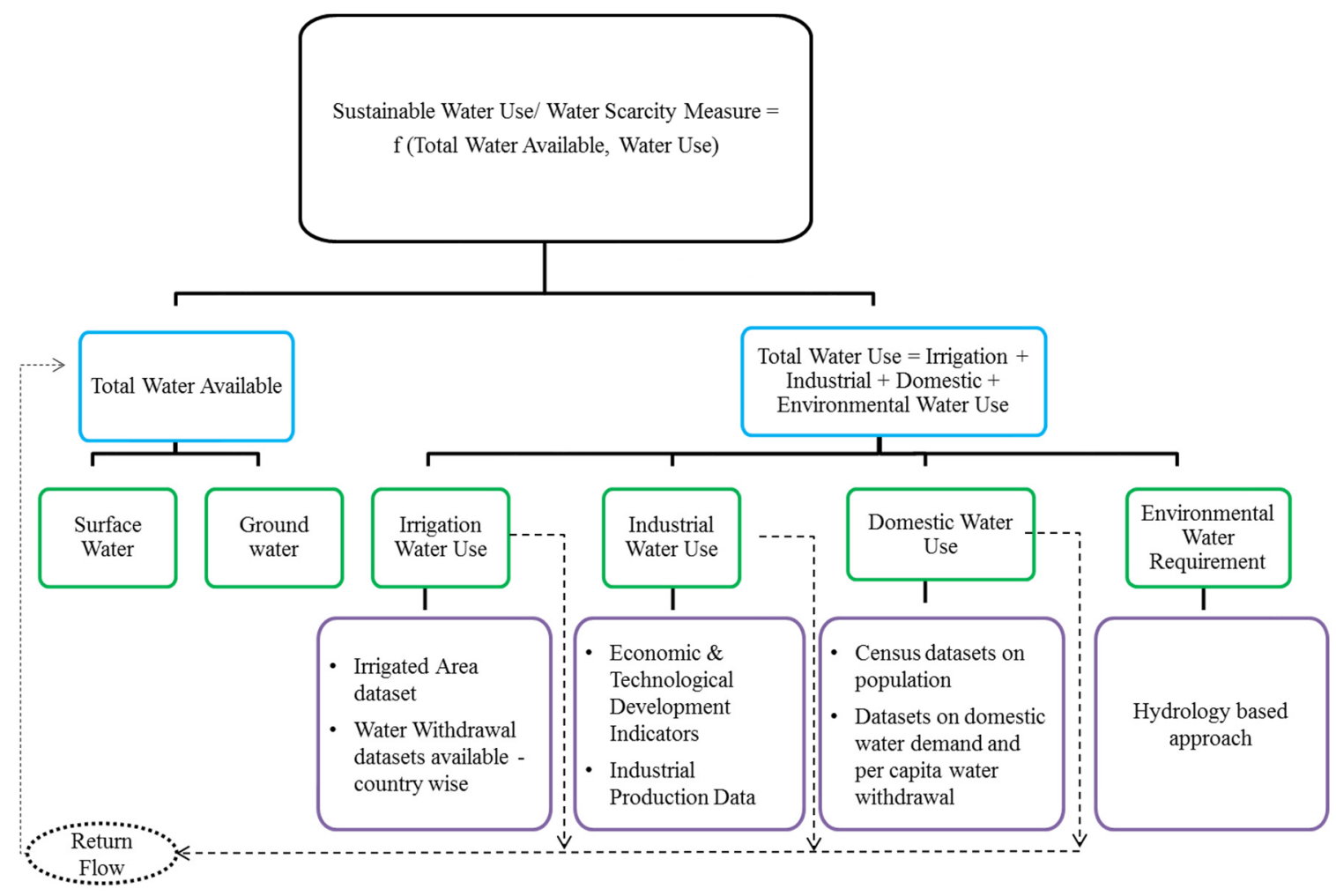

Figure 1. Modelling framework for sustainable water use quantification in India

\section{ESTIMATION OF SURFACE WATER COMPONENT}

The Community Land Surface Model CLM 4.0, which is the land surface representation of Community Earth System Model (CESM) developed by the National Centre for Atmospheric Research (NCAR) is used for estimating total runoff (Oleson et al., 2010). For each grid-cell, there are multiple land units including glacier, wetland, vegetated, lake and urban, ten different soil columns and 17 different plant functional types that characterise land cover in the model. The surface runoff consists of overland flow due to saturation excess and infiltration excess mechanism. Drainage or sub-surface flow is estimated as a function of water table depth. The model results are at a spatial resolution of $50 \mathrm{~km}$ x $50 \mathrm{~km}$ at a monthly time scale from 1950 to 2002. The three simulation cases, control run (with no irrigation), irrigation data of Wisser et al. (2010) and irrigation data based on census data sets (Datanet-India, 2011) are used in this study. These simulation cases are denoted as CTRL, IRR: Indiastat and IRR: Wisser respectively. Discharge observations for the three major river basins of India, namely Krishna (1965 - 2000), Narmada (1990 - 1996), Godavari (1990 2000) and Mahi (1986 - 1995) are used to calibrate the model (CWC, 2005). The observed discharge is at the outlet of each basin, and considering the time for the runoff to reach the outlet, modelled runoff at the annual time-scale is used for the calibration. 
Joseph et al., Investigation of sustainable national water resources management of India in a changing climate

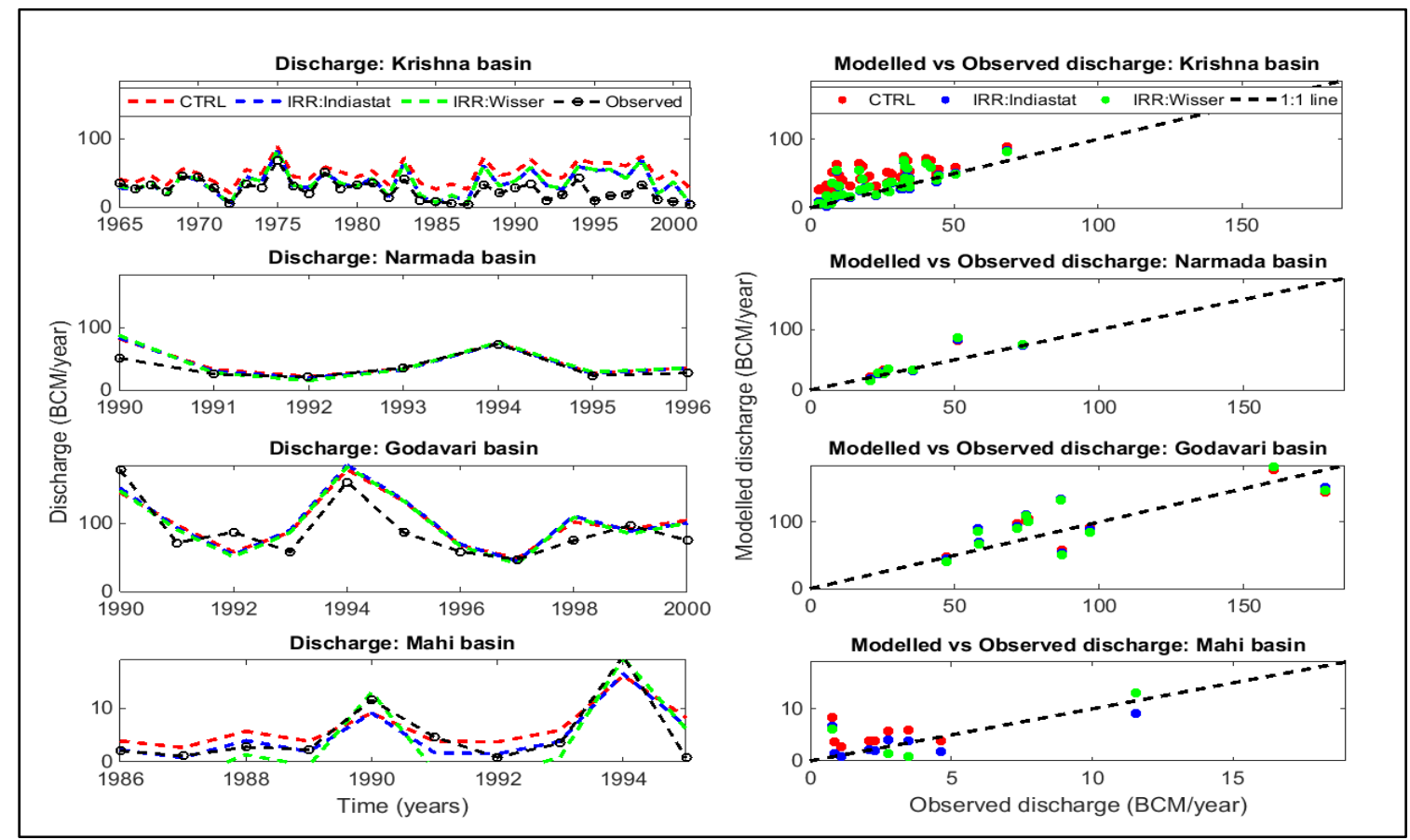

Figure 2. Annual runoff modelled and observed discharge at Krishna, Narmada, Godavari and Mahi river

Figure 2 shows observed discharge and total modelled runoff, the sum of surface and sub-surface runoff, together with the 1:1 line. Table 1 presents the model performance statistics, R-squared, Root Mean Squared Error (RMSE) and Nash-Sutcliffe Efficiency (NSE). As shown in Figure 2, the model results are in good agreement with the discharge observations except for the Krishna river basin. For the Krishna river basin, the model results match the observed discharge data for the period 1965 to 1982. The model, however, overestimated runoff from 1982 to 2000, during the semi-arid period of the basin. For the Narmada, Godavari and Mahi river basins, the modelled runoff is in agreement with the observed discharge with better performance indices (Table 1). Based on these results, surface runoff obtained from CLM 4.0 is used as the surface water component of the total water available (Figure 1).

Table 1. Model statistics for the four river basins

\begin{tabular}{|c|c|c|c|c|c|}
\hline River basin & Gauge Location & Stats & Control & IRR: Indiastat & IRR: Wisser \\
\hline \multirow{3}{*}{ Krishna } & \multirow{3}{*}{ Vijayawada } & R-squared & 0.67 & 0.73 & 0.73 \\
\hline & & RMSE & 26.87 & 16.50 & 16.70 \\
\hline & & NSE & -2.33 & -0.26 & -0.29 \\
\hline \multirow{3}{*}{ Narmada } & \multirow{3}{*}{ Gurudeshwar } & R-squared & 0.89 & 0.88 & 0.88 \\
\hline & & RMSE & 12.65 & 12.98 & 14.54 \\
\hline & & NSE & 0.49 & 0.47 & 0.33 \\
\hline \multirow{3}{*}{ Godavari } & \multirow{3}{*}{ Polavaram } & $\mathrm{R}$-squared & 0.81 & 0.81 & 0.80 \\
\hline & & RMSE & 26.26 & 27.51 & 27.12 \\
\hline & & NSE & 0.57 & 0.52 & 0.54 \\
\hline \multirow{3}{*}{ Mahi } & \multirow{3}{*}{ Khanpur } & R-squared & 0.89 & 0.91 & 0.9 \\
\hline & & RMSE & 3.28 & 2.48 & 3.65 \\
\hline & & NSE & 0.68 & 0.81 & 0.6 \\
\hline
\end{tabular}

\section{ESTIMATION OF DOMESTIC AND INDUSTRIAL WATER DEMANDS}

\subsection{Domestic water demand}

Domestic water demand is estimated in this study as a product of population and per-capita water use. Several large-scale assessments adopted a similar methodology, but the temporal variation of per-capita water use was not addressed (Mitchell and Jones, 2005; Wada et al., 2011a; Wada et al., 2011b). The present study observes that the per-capita domestic water demand has been increasing in India in the past due to the 
Joseph et al., Investigation of sustainable national water resources management of India in a changing climate

economic development. Also, the population exhibits an increasing linear trend whereas the domestic water demand shows an exponential growth starting in 1990, consistent with the exponential growth of India's GDP. Based on these observations, the present study use GDP per person as an indicator to model per-capita water use variations in India (Oki and Kanae, 2006).

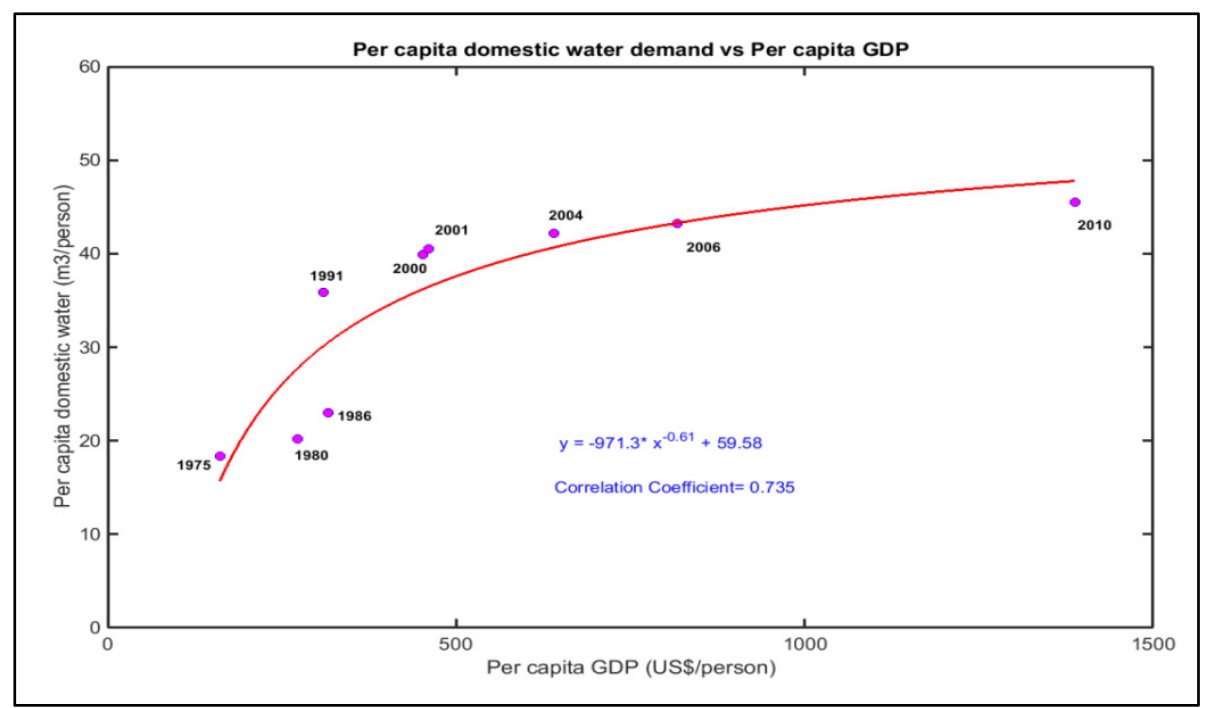

Figure 3. Per capita domestic water demand vs per capita GDP with power function model

A power function model is used for modelling per-capita domestic water demand in this study as shown in Figure 3. The Levenberg-Marquardt algorithm is used to fit the power function (Figure 3), and the model performance statistics show better agreement with the observed values (Sum of the square of errors (SSE) 190.9, R-squared - 0.79, Adjusted R-squared - 0.72, RMSE - 5.64). The modelled per-capita domestic water demand is then multiplied by population to estimate the total domestic water demand. The model results show good agreement with the observed domestic water demand $(\mathrm{R}$-squared $=0.96, \mathrm{NSE}=0.90)$. The same model is applied at the State-level, and it is matching with the observed values of domestic water demand for the years 1991, 2001, 2004 and 2006, as shown in Figure 3.

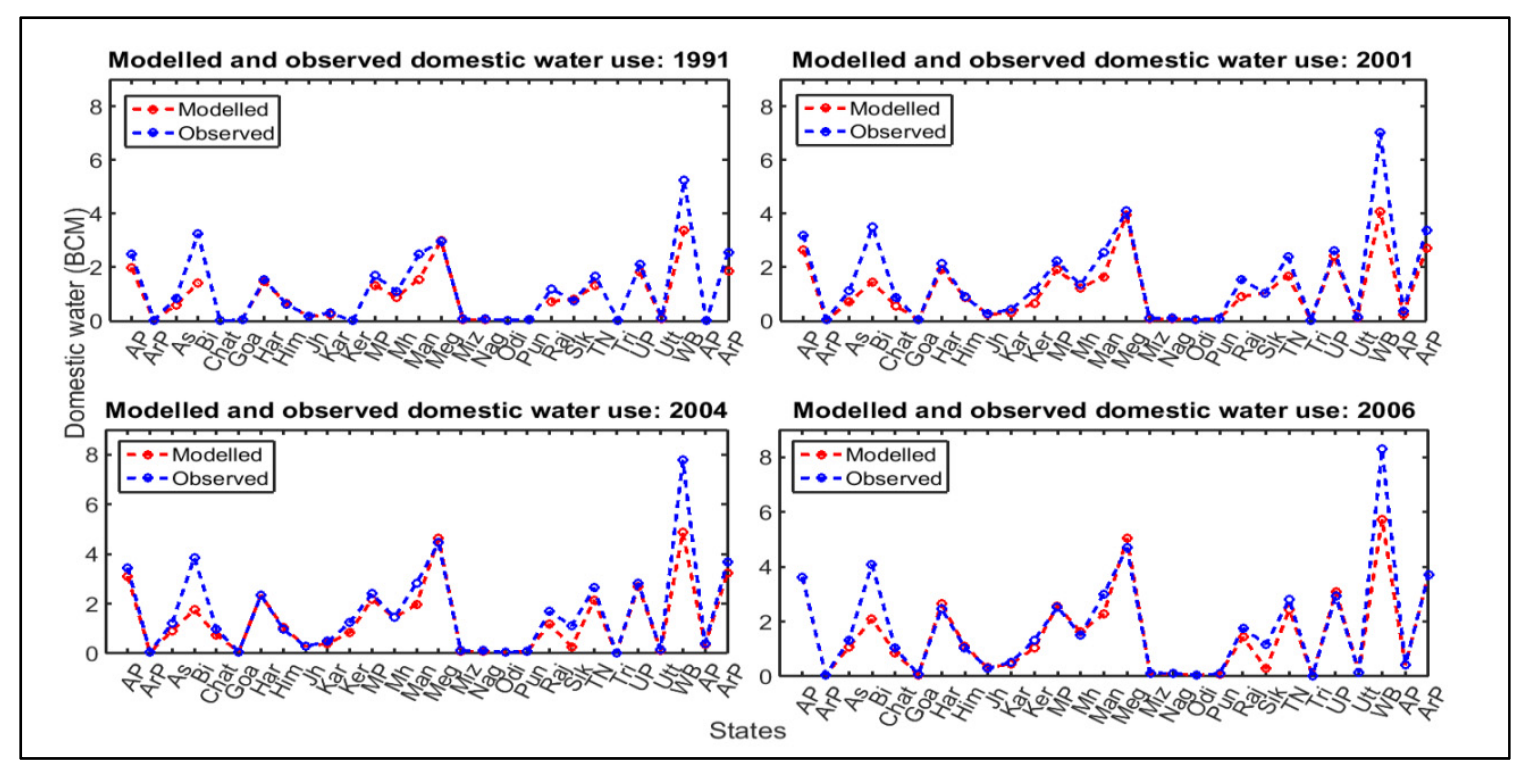

Figure 3. State-level domestic water demand vs Observed for 1991, 2001, 2004 and 2006 (x-axis: abbreviations for each state in India, Units - BCM)

\subsection{Industrial water demand}

Industrial water demand data in India is very scarce, and there are serious discrepancies between the estimates and observations by various agencies such as FAO, World-bank, NCIWRD, Indiastat, Centre for Science and Environment (CSE) and SSE-MoWR (Standing Sub-committee of Ministry of Water 
Joseph et al., Investigation of sustainable national water resources management of India in a changing climate

Resources), as shown in Figure 4. The estimations from FAO and World-bank show an inconsistent trend pattern. Conversely, the estimate from NCIWRD follows a consistent increasing trend, and it is based on the survey from 17 categories of industries in India. This data-set is widely accepted by many national government agencies such as Central Water Commission (CWC) and CSE. The NCIWRD estimate shows high correlation with GDP (0.98), electricity consumption (0.99) and population (0.94). However, these indicators cannot account for the structural change in industries including the production (52 different industries) and consumables (29 survey characteristics) of the industrial sector in India. Building a model with a large number of inputs may result in over-fitting of the model. To avoid this problem, Principal Component Analysis is performed on the data-set to reduce the number of correlated variables into a more compact set of orthogonal predictors (Rencher, 2002). These components are used to model the industrial water demand using a linear function. The linear model is selected as these components are developed by the linear association between the variables. The model is calibrated using the three NCIWRD observations and validated using the CSE observation for the year 2001. The modelled against observed data with the 1:1 line added is shown as an inset in Figure 4. The model results closely match with the observed value from NCIWRD and CSE. The national-level model estimate is distributed to each state based on the number of industrial units, and the results are in agreement with the census data sets collected at the state-level.

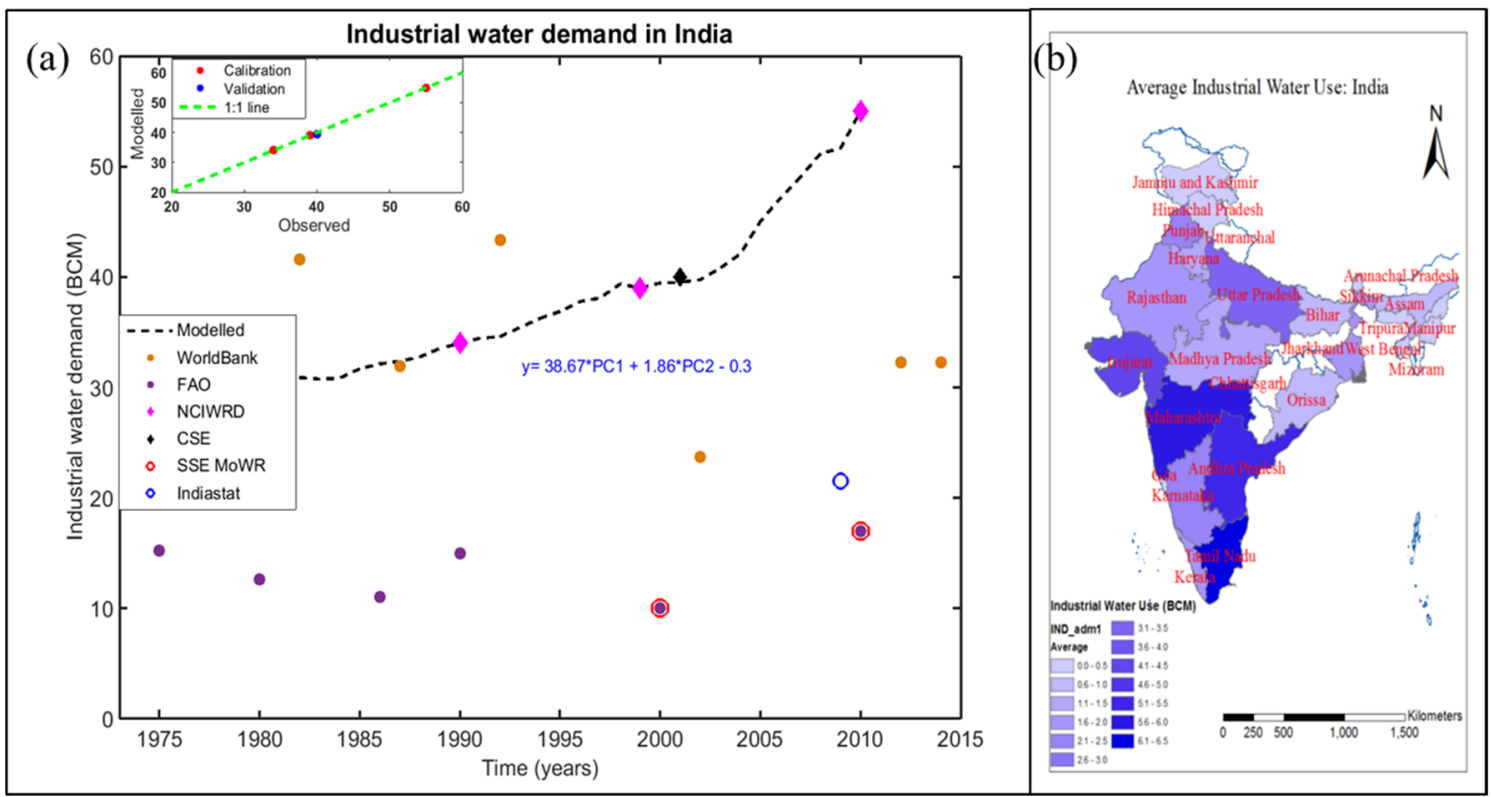

Figure 4. (a) Industrial water demand modelled and observations from various sources, (b) State-wise average industrial water use in India for the period 1991 to 2010

\section{CONCLUSIONS}

The present study discusses a large-scale sustainable water use assessment modelling framework and the results of the three most important elements of the framework in India. The runoff component of the CLM model exhibited good model performance indices for the calibration in the Narmada, Godavari and Mahi river basins of India and over-estimated for Krishna river basin. The industrial and domestic water demand components are based on census database, and the model results are superior over those of the FAO estimates of water demand. The study highlights the need to include the structural change of industries in industrial water demand modelling and the change of per-capita water use in domestic water demand modelling.

\section{REFERENCES}

Alcamo, J. et al. (2003). Development and testing of the WaterGAP 2 global model of water use and availability. Hydrological Sciences Journal, 48(3): 317-337.

Alcamo, J., Flörke, M., Märker, M. (2007). Future long-term changes in global water resources driven by socio-economic and climatic changes. Hydrological Sciences Journal, 52(2): 247-275.

Alcamo, J., Henrichs, T., Rosch, T. (2000). World water in 2025: Global modeling and scenario analysis. World water scenarios analyses.

Amarasinghe, U. et al. (2005). Spatial variation in water supply and demand across river basins of India, 83. Iwmi. 
Joseph et al., Investigation of sustainable national water resources management of India in a changing climate

Bhat, T.A. (2014). An Analysis of Demand and Supply of Water in India. Journal of Environment and Earth Science, 4(11): 67-72.

CWC (2005). Integrated Hydrological Data Book. Central Water Commission, New Delhi.

Datanet-India (2011). Indiastat. com. In: Thukral, R.K. (Ed.), New Delhi: Datanet India.

Hanasaki, N. et al. (2008). An integrated model for the assessment of global water resources-Part 2: Applications and assessments. Hydrology and Earth System Sciences, 12(4): 1027-1037.

Hoekstra, A.Y., Mekonnen, M.M. (2012). The water footprint of humanity. Proceedings of the National Academy of Sciences, 109(9): 3232-3237.

Hoekstra, A.Y., Mekonnen, M.M., Chapagain, A.K., Mathews, R.E., Richter, B.D. (2012). Global monthly water scarcity: blue water footprints versus blue water availability. PLoS One, 7(2): e32688.

Kumar, M.D. (2003). Food security and sustainable agriculture in India: the water management challenge, 60. IWMI.

Kummu, M., Ward, P.J., de Moel, H., Varis, O. (2010). Is physical water scarcity a new phenomenon? Global assessment of water shortage over the last two millennia. Environmental Research Letters, 5(3): 034006.

Mekonnen, M.M., Hoekstra, A.Y. (2016). Four billion people facing severe water scarcity. Science Advances, 2(2): e1500323.

Mitchell, T.D., Jones, P.D. (2005). An improved method of constructing a database of monthly climate observations and associated high-resolution grids. International Journal of Climatology, 25(6): 693-712.

NCIWRD (1999). Integrated water resources development. A plan for action. Report of the Commission for Integrated Water Resource Development Volume 1, Ministry of Water Resources, Government of India, New Delhi, India.

Oki, T. et al. (2001). Global assessment of current water resources using total runoff integrating pathways. Hydrological Sciences Journal, 46(6): 983-995.

Oki, T., Kanae, S. (2006). Global hydrological cycles and world water resources. Science, 313(5790): 10681072.

Oleson, K.W. et al. (2010). Technical description of version 4.0 of the Community Land Model (CLM).

Pastor, A., Ludwig, F., Biemans, H., Hoff, H., Kabat, P. (2014). Accounting for environmental flow requirements in global water assessments. Hydrology and Earth System Sciences, 18(12): 5041-5059.

Rencher, A.C. (2002). Principal component analysis. Methods of Multivariate Analysis, Second Edition: 380407.

Rosegrant, M.W., Ringler, C., Zhu, T. (2009). Water for agriculture: maintaining food security under growing scarcity. Annual Review of Environment and Resources, 34: 205-222.

Seckler, D., Amarasinghe, U., Molden, D., de Fraiture, C. (2000). World water supply and demand, 1995 to 2025. Colombo, Sri Lanka: International Water Management Institute.

Siebert, S., Döll, P. (2010). Quantifying blue and green virtual water contents in global crop production as well as potential production losses without irrigation. Journal of Hydrology, 384(3): 198-217.

Smakhtin, V., Revenga, C., Döll, P. (2004). Taking into account environmental water requirements in globalscale water resources assessments, 2. IWMI.

Wada, Y., Van Beek, L., Bierkens, M.F. (2011a). Modelling global water stress of the recent past: on the relative importance of trends in water demand and climate variability. Hydrology and Earth System Sciences, 15(12): 3785-3808.

Wada, Y. et al. (2011b). Global monthly water stress: 2. Water demand and severity of water stress. Water Resources Research, 47(7).

Wada, Y., Wisser, D., Bierkens, M. (2014). Global modeling of withdrawal, allocation and consumptive use of surface water and groundwater resources. Earth System Dynamics, 5(1): 15.

Wisser, D. et al. (2010). The significance of local water resources captured in small reservoirs for crop production-A global-scale analysis. Journal of Hydrology, 384(3): 264-275. 